\title{
Techniques for controlled synthesis of the Douglas-fir - Laccaria laccata ectomycorrhizal symbiosis
}

\author{
R Duponnois ${ }^{*}$, J Garbaye 2 \\ ${ }^{1}$ BIOCEM, Laboratoire de Technologie des Semences, avenue du Bois l'Abbé, \\ 49070 Beaucouzé; \\ 2 INRA, Centre de Recherches Forestières de Nancy, Champenoux, 54280 Seichamps, France
}

(Received 7 February 1991; accepted 16 August 1991)

Summary - Laccaria laccata (Scop ex Fr) Cke is an ectomycorrhizal basidiomycete which is very efficient for the controlled mycorrhization of Douglas-fir (Pseudotsuga taxifolia Poir Britt). Studying the biology of this symbiosis led to the development of a number of experimental techniques for aseptic and non-aseptic synthesis. This paper describes seed treatements, fungal inoculum preparation, substrates, nutrient solutions, aseptic experimental systems (test tubes and Petri dishes) and non-aseptic systems (pot experiments in the glasshouse) and bare-root nursery techniques. The specificity of each technique is discussed according to the experimental purpose.

ectomycorrhizas / aseptic synthesis / non-aseptic synthesis / Pseudotsuga taxifolia / Laccaria laccata

Résumé - Techniques d'étude de la symbiose ectomycorhizienne entre le douglas et Lacarria laccata. Laccaria laccata (Scop ex Fr) Cke est un champignon basidiomycète ectomycorhizien très efficace pour la mycorhization contrôlée du douglas (Pseudotsuga taxifolia Por Britt). L'étude de la biologie de cette symbiose a conduit à la mise au point d'un certain nombre de techniques expérimentales pour réaliser sa synthèse en conditions aseptiques ou non aseptiques. Cette note décrit le traitement des graines, la préparation de l'inoculum fongique, les solutions nutritives, les substrats, les systèmes expérimentaux aseptiques (tubes à essais [fig 1] et boîtes de Petri [fig 2]) et non aseptiques (expériences en pots en serre [figs $3,4,5,6]$ et techniques de pépinière à racines nues). Les techniques aseptiques in vitro permettent d'étudier l'effet de divers facteurs expérimentaux sur la dynamique de l'infection ectomycorhizienne, mais pas l'effet de la mycorhization sur la croissance de la plante. Cet effet se manifeste en serre et en pépinière. Certains des dispositifs proposés pour les expériences en serre permettent l'observation directe et non destructive du système racinaire.

ectomycorhizes / synthèses axéniques / synthèses non-axéniques / Pseudotsuga taxlfolia / Laccaria laccata

\footnotetext{
* Present address: As for J Garbaye (2)
} 


\section{INTRODUCTION}

Douglas-fir is presently the dominant forest tree species used for reforestation in France. Field experiments have shown that the ectomycorrhizal fungus Laccaria laccata, when inoculated to planting stocks in the nursery, stimulates the early growth of outplanted Douglas fir (Molina, 1980; Le Tacon et al, 1983, 1985, 1988; Mortier et al, 1988).

As practical applications of these results are developing, different aspects of the association are being investigated by INRA in order to improve performance and to select more efficient fungal strains. The physiology of the symbiosis is studied in aseptic in vitro systems, and experiments in glasshouse and nursery conditions are carried out in order to study how mycorrhizal establishment is affected by environmental factors and compare the behavior of inoculated and non-inoculated seedlings submitted to different treatments, in conditions close to practice.

The aim of this note is to help readers working on similar symbiotic systems choose the technic the best adapted to their own experimental purpose.

\section{PRODUCTION OF FUNGAL INOCULUM}

\section{Maintenance of the fungal strain}

The ectomycorrhizal basidiomycete Laccaria laccata (Scop ex Fr) Cke isolate S238 from USDA (Corvallis, OR) is maintained in Petri dishes $(6 \mathrm{~cm}$ diameter) on modified Pachlewski agar medium (Pachlewski and Pachlewska, 1974). The composition is for 1 liter as follows: diammonium tartrate: $0.5 \mathrm{~g} ; \mathrm{KH}_{2} \mathrm{PO}_{4}: 0.5 \mathrm{~g}$; $\mathrm{MgSO}_{4}, 7 \mathrm{H}_{2} \mathrm{O}: 0.5 \mathrm{~g}$; maltose: $5.0 \mathrm{~g}$; glucose: $20 \mathrm{~g}$; thiamine: $1 \mu \mathrm{g}$ : Fe EDTA: 0.6 $\mathrm{mg}$; Mo: $0.03 \mathrm{mg} ; \mathrm{B}: 0.13 \mathrm{mg}$; Mn: $0.5 \mathrm{mg}$; $\mathrm{Cu}: 0.06 \mathrm{mg}$; Zn: $0.23 \mathrm{mg}$; Agar: $20 \mathrm{~g}$. Micronutrients ( $\mathrm{Fe}, \mathrm{Mo}, \mathrm{B}, \mathrm{Mn}, \mathrm{Cu}$ and $\mathrm{Zn}$ ) are applied together as $0.1 \mathrm{ml}$ of a concentrated commercial solution: Kanieitra (COFAZ, BP 198-08, Paris, France). Cultures are kept at $25{ }^{\circ} \mathrm{C}$ in a dark incubation chamber. When growing, the mycelium develops a bright lilac color, which reaches maximal intensity after 1 month. Cultures are transferred into fresh medium after 2 months, when the colonies have a diameter of about $4 \mathrm{~cm}$.

\section{Liquid inoculum}

$L$ laccata is grown in 1-liter Erlenmeyer flasks stoppered with cotton wool and containing $500 \mathrm{ml}$ of liquid modified Pachlewski medium. The flasks are inoculated with 8 agar disks (6 $\mathrm{mm}$ diameter) cut from the margin of a culture on modified Pachlewski agar medium. After 2 weeks, the mycelium develops a lilac color which permits detection of contaminants. This typical colour does not develop as well in other media such as Melin (Melin, 1936), malt extract or brewery wort. Flasks are kept in the dark at $25^{\circ} \mathrm{C}$ on an orbital shaker for 1 month. The mycelium is then washed in tap water in order to remove residual nutrients, homogenized in a Waring blender for $\approx 10 \mathrm{~s}$ and resuspended in distilled water. This kind of fungal inoculum is quantified by measuring the fungal dry weight per $\mathrm{ml}$ or by counting living propagules (determination of colony forming units by spreading $1 \mathrm{ml}$ of suspension on a $6-\mathrm{cm}$ Petri dish with nutrient agar). The viability of the suspension does not decrease before 4 weeks at $4{ }^{\circ} \mathrm{C}$.

\section{Vermiculite-peat inoculum (adapted from Marx and Bryan, 1975)}

Glass jars (1.6 I) containing 1.3 I expanded vermiculite-sphagnum peat mixture (4:5- 
$1: 5, \mathrm{v}: \mathrm{v}, \mathrm{pH}=5.5)$ are autoclaved $\left(120^{\circ} \mathrm{C}\right.$, $20 \mathrm{~min}$ ). Another ratio of vermiculite-peat can be used $(2: 3-1: 3)$. The peat can release some substances which are toxic for fungal growth. For this reason, the first ratio mixture is preferred. Then the mixture is moistened to field capacity with $600 \mathrm{ml}$ modified liquid Pachlewski medium. The jars are stoppered with lids with a 1-cm diameter hole. This hole is fitted with a $4-\mathrm{cm}$ long tube filled with cotton wool. The jars are then autoclaved a second time $\left(120^{\circ} \mathrm{C}\right.$ for $20 \mathrm{~min}$ ). After cooling, 8 mycelial plugs are laid on top of the substrate. Mycelium grows down into the substrate, which is completely colonized after 6 weeks at $25^{\circ} \mathrm{C}$. For faster growth, jars can be filled with a smaller quantity of substrate and shaken after mycelia have colonized a few centimeters: in this manner, mycelium is evenly distributed throughout the substrate and incubation time is shortened. This inoculum can be stored at $4{ }^{\circ} \mathrm{C}$ for up to 6 months.

\section{Alginate beads inoculum}

The process of including fungal mycelium in polymeric gels (especially calcium alginate) has been previously described (Dommergues et al, 1979; Le Tacon et al, 1983, 1985). The inoculum prepared in this manner is more efficient than the classical vermiculite-peat inoculum (Mortier et al, 1988) because the mycelium is protected in the gel from physical stresses (eg water stress) and from competitor microorganisms. With this technique, it is possible to accurately control the weight of mycelium or the number of living propagules contained in the inoculum. Different attempts have been made to measure the quantity of mycelium in the vermiculite-peat inoculum: ergosterol assay (Martin et al, 1990); chitin assay (Vignon et al, 1986), but none of them gave reliable results (Mortier et al, 1988 ) because of the peat which interferes with colorimetric measurements.

A mycelial suspension, obtained as previously described, is mixed $(1: 1, v: v)$ with distilled water containing $20 \mathrm{~g} \mathrm{I}^{-1}$ sodium alginate and $50 \mathrm{~g} \mathrm{I}^{-1}$ autoclaved dry powdered sphagnum peat. When aseptic inoculum is needed, the alginate solution and the peat should be autoclaved separately. The final solution is pumped throught a pipe with 2-mm holes. The drops fall into a $100 \mathrm{~g} \mathrm{I}^{-1} \mathrm{CaCl}_{2}$ solution and form beads of reticulated calcium alginate gel (Mauperin et al, 1987). The beads are kept in $\mathrm{CaCl}_{2}$ for $24 \mathrm{~h}$ at room temperature in order to ensure complete reticulation. They are then washed with tap water to remove $\mathrm{NaCl}$ and $\mathrm{CaCl}_{2}$ and stored in air-tight containers at $4{ }^{\circ} \mathrm{C}$ in order to prevent drying. This type of inoculum can be kept up to 9 months in these conditions. The beads are prepared with 1-2 g mycelium (dry weight) per I of final solution (Mortier et al, 1988).

\section{ASEPTIC MYCORAHIZAL SYNTHESIS}

As for all the techniques described below, the seeds of Douglas-fir (Pseudotsuga taxifolia (Poir) Britt (syn $P$ douglasii (Lindl) Carr, syn $P$ menziesii (Mirb) Franco, syn $P$ mucronata (Raf) Sudw) are from provenance zone 412 (Snoqualmie Falls, Washington State, USA). They are supplied by Vilmorin (La Ménitré, 49250 Beaufort-enVallée, France).

All the aseptic experimental systems presented here are designed for studying the dynamics of symbiosis establishment between the plant and the fungus. Howev$\mathrm{er}$, due to the limited volume of the vessel containing the roots, they are not suitable for the expression of a growth effect on the plant. 
Root exudates provide the carbon needed for the fungal growth (Harley and Smith, 1983). The release of these substances is linked to photosynthesis (Hacskalylo, 1973). Therefore, in order to obtain normal photosynthesis, the aerial part of the plant is kept under non-axenic conditions outside the tube or the Petri dish and the roots are kept inside the culture vessel under axenic conditions. If the aerial part of the plant were kept inside, parameters affecting gas exchange (temperature, $\mathrm{CO}_{2}$, humidity) would be altered.

Cultures are set in a climate-controlled growth chamber with $23^{\circ} \mathrm{C}$ day, $17^{\circ} \mathrm{C}$ night, $16 \mathrm{~h}$ photoperiod with $240 \mu \mathrm{E} \cdot \mathrm{m}^{-2} . \mathrm{s}^{-1}$ (Mazda MAlH 400 lamps), $80 \%$ relative humidity.

The seeds are surface-sterilized in $30 \%$ $\mathrm{H}_{2} \mathrm{O}_{2}$ for $90 \mathrm{~min}$, washed for $4 \mathrm{~h}$ in sterile water, and plated on glucose (1 $\left.\mathrm{g} .^{-1}\right)$ agar in order to detect contamination. Contaminated seeds are discarded and germinants are used when taproots are 1-2 cm long.

\section{Test-tube system (fig 1)}

The 2 components of the system (fungus, plant) are aseptically confronted in glass test-tubes $(3 \times 15 \mathrm{~cm})$ filled with autoclaved $\left(120^{\circ} \mathrm{C}, 20 \mathrm{~min}\right)$ peat-vermiculite $(1: 1, v: v)$ moistened to field capacity with modified Shemakanova mineral nutrient solution (Shemakanova, 1962): $\mathrm{MgSO}_{4}$, $7 \mathrm{H}_{2} \mathrm{O}: 150 \mathrm{mg} ;\left(\mathrm{NH}_{4}\right)_{2} \mathrm{HPO}_{4}: 125 \mathrm{mg}$; $\left(\mathrm{NH}_{4}\right)_{2} \mathrm{SO}_{4}: 125 \mathrm{mg} ; \mathrm{CaCl}_{2}, 2 \mathrm{H}_{2} \mathrm{O}: 50 \mathrm{mg}$; $\mathrm{KCl}: 108 \mathrm{mg}$; Kanieltra: $0.1 \mathrm{ml}$; distilled water: 1 liter). Fungal inoculation can be achieved with peat-vermiculite inoculum (either mixed throughout the substrate $(1: 10, v: v)$ or laid on top of the tube (1-2 $\mathrm{cm}$ ), alginate beads ( 5 beads laid on top of the tube) or mycelium suspension (injected with a syringe or deposited with a pipette). The tubes are covered with alumin-

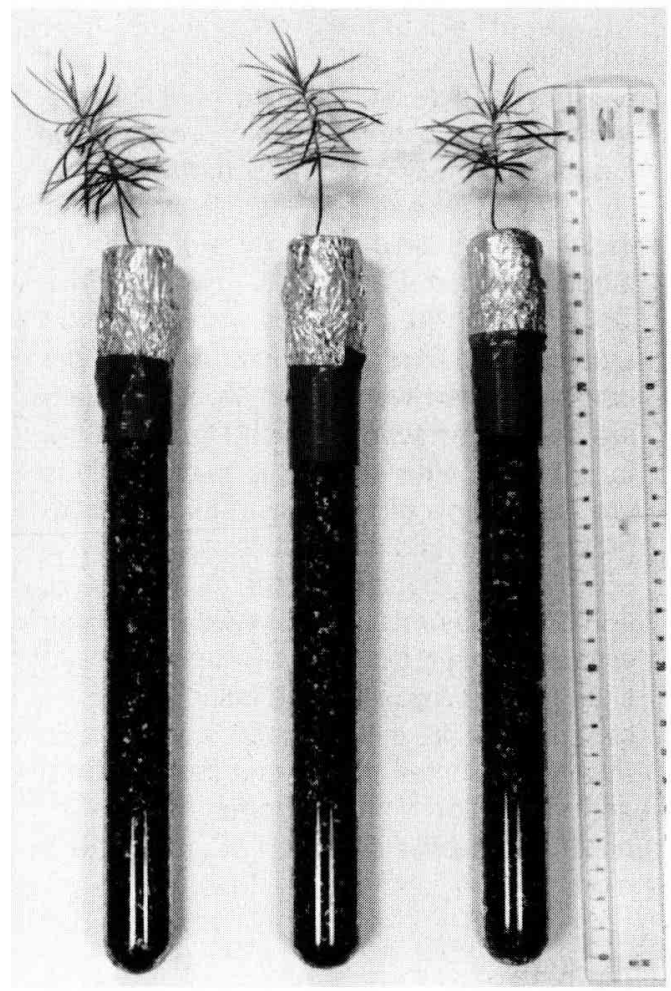

Fig 1. Four-week-old Douglas fir seedlings in test-tubes with vermiculite-peat substrate. The substrate and the root system are kept aseptic by a putty seal.

ium foil and the rootlet of one aseptically germinated seed is introduced through a hole in the foil and sealed with autoclaved coachwork putty (Terosta 2, Teroson SA, Asnières, France). The roots are maintained in axenic conditions, while the aerial part of the plant develops outside the tube.

After 1 month of culture, the plant is removed from the tube and roots are observed with a stereomicroscope. Each seedling bears $\approx 100$ short roots, $30-100 \%$ of them being mycorrhizal with Laccaria laccata, depending on variable factors. 


\section{Petri dish systems (fig 2)}

Circular (diameter $=12 \mathrm{~cm}$ ) or square $(12$ $x 12 \mathrm{~cm}$ ) Petri dishes can be used. They are filled to the lid with substrate: autoclaved soil, autoclaved silica sand (0.5-1.2 $\mathrm{mm}$ ) washed with $6 \mathrm{~N} \mathrm{HCl}$ and rinsed with tap water or vermiculite-peat mixture (1:1, $v: v)$. Soil is moistened to field capacity with distilled water and the 2 other substrates with modified Shemakanova nutrient solution.

The rootlets or 2 or 3 aseptically germinated seeds are introduced through holes 2-3 cm apart in the side wall of the dish and sealed with autoclaved coachwork putty. The lid is sealed with plastic adhesive tape. The dishes are set upside down at a $45^{\circ}$ angle in the grown chamber, so that roots grow down against the lid. As in test tubes, mycorrhiza can be obtained after 1 month of culture, with the same number of short roots per plant and the same mycorrhizal infection rate.

Compared with the test tubes, this Petri dish system enables observation of the roots through the lid with a stereomicroscope (monitoring root and fungal growth, counting mycorrhizas, etc). Dishes can also be opened under sterile atmosphere for root sampling or addition of various inocula or chemicals.

\section{NON-ASEPTIC SYNTHESIS IN THE GLASSHOUSE}

Before sowing, Douglas-fir seeds are either pretreated in moist sphagnum peat for

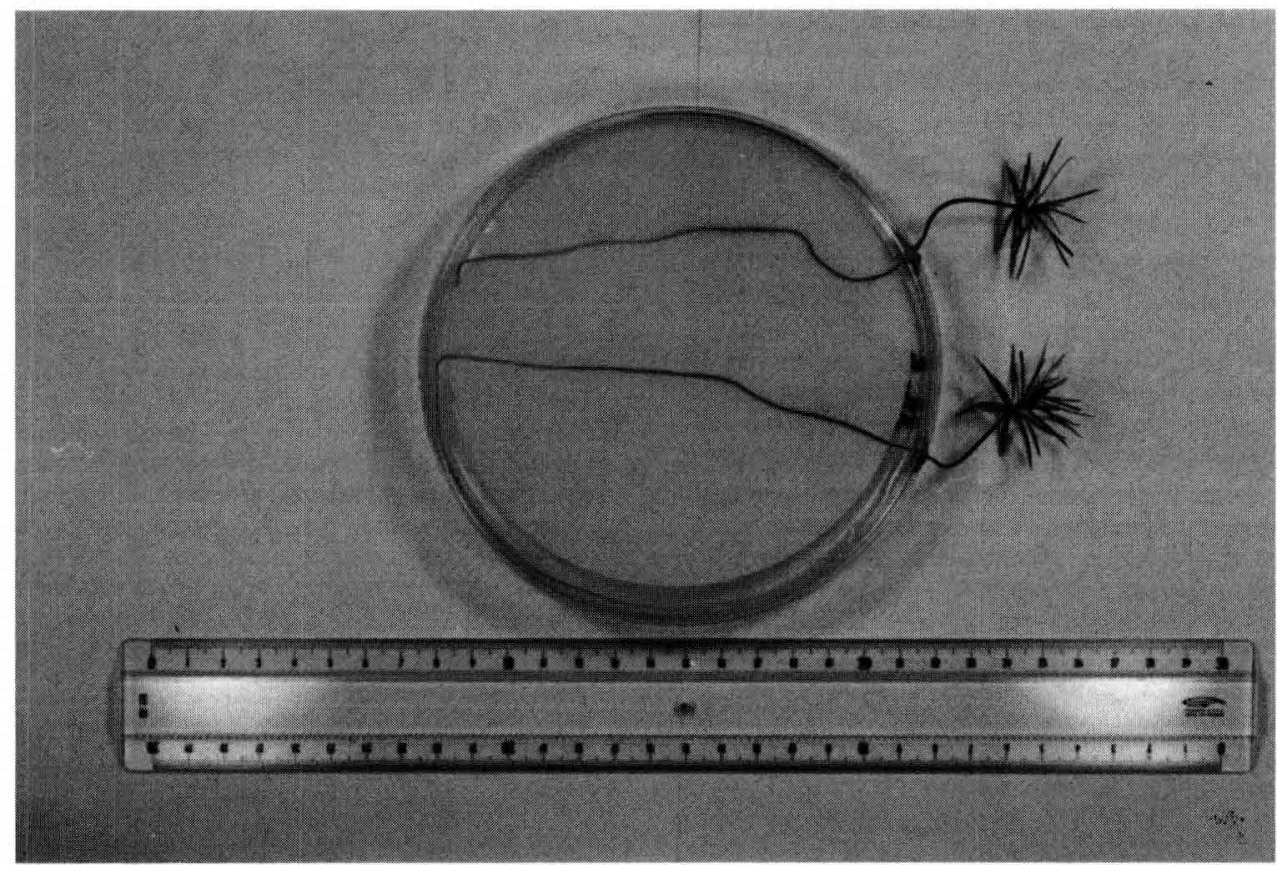

Fig 2. Two-week-old Douglas-fir seedlings in a Petri dish (substrate removed to show roots). The content of the dish and the root system are kept aseptic by a putty seal. 
8 weeks at $4{ }^{\circ} \mathrm{C}$ or surface sterilized in $30 \% \mathrm{H}_{2} \mathrm{O}_{2}$ for $90 \mathrm{~min}$, washed for $4 \mathrm{~h}$ in sterile water and kept overnight in water at $4^{\circ} \mathrm{C}$. The germination rate is better with the first technique but the risks of damping off due to Rhizoctonia spp, Fusarium spp or other pathogens is higher. The method using $\mathrm{H}_{2} \mathrm{O}_{2}$ eliminates the pathogens and suppresses seed dormancy.

The seedlings can be grown on soil (disinfected or not by steam or methyl bromide fumigation) or non-disinfected vermiculite-peat mixture $(1: 1, v: v)$. Several kinds of container can be used for growing Douglas fir seedlings in the glasshouse, depending on the aim of the experiment.

\section{Hiko containers (fig 3)}

The black high-density cast polyethene Hiko containers are manufactured in Swe- den. They are trays containing 24 or 40 cells of 150 or $93 \mathrm{~cm}^{3}$, respectively. They are easy to fill and occupy the room in the glasshouse very efficiently. However, holes at the bottom are wide and flowing substrates such as sandy soils have to be maintained by peat or glass-wool plugs. Another drawback is that Hiko containers cannot be opened. One seedling is grown in each cell.

\section{Transparent boxes (fig 4)}

These are $20 \times 7.5 \times 2.2 \mathrm{~cm}$ clear polystyrene boxes (Ref LH 275.22, Etablissements Caubère, Paris, France). One extremity is cut open and three $1-\mathrm{cm}$ holes are bored in the other end in order to ensure drainage. Boxes are wrapped with black polythene film to prevent green algae proliferation, and maintained inclined at

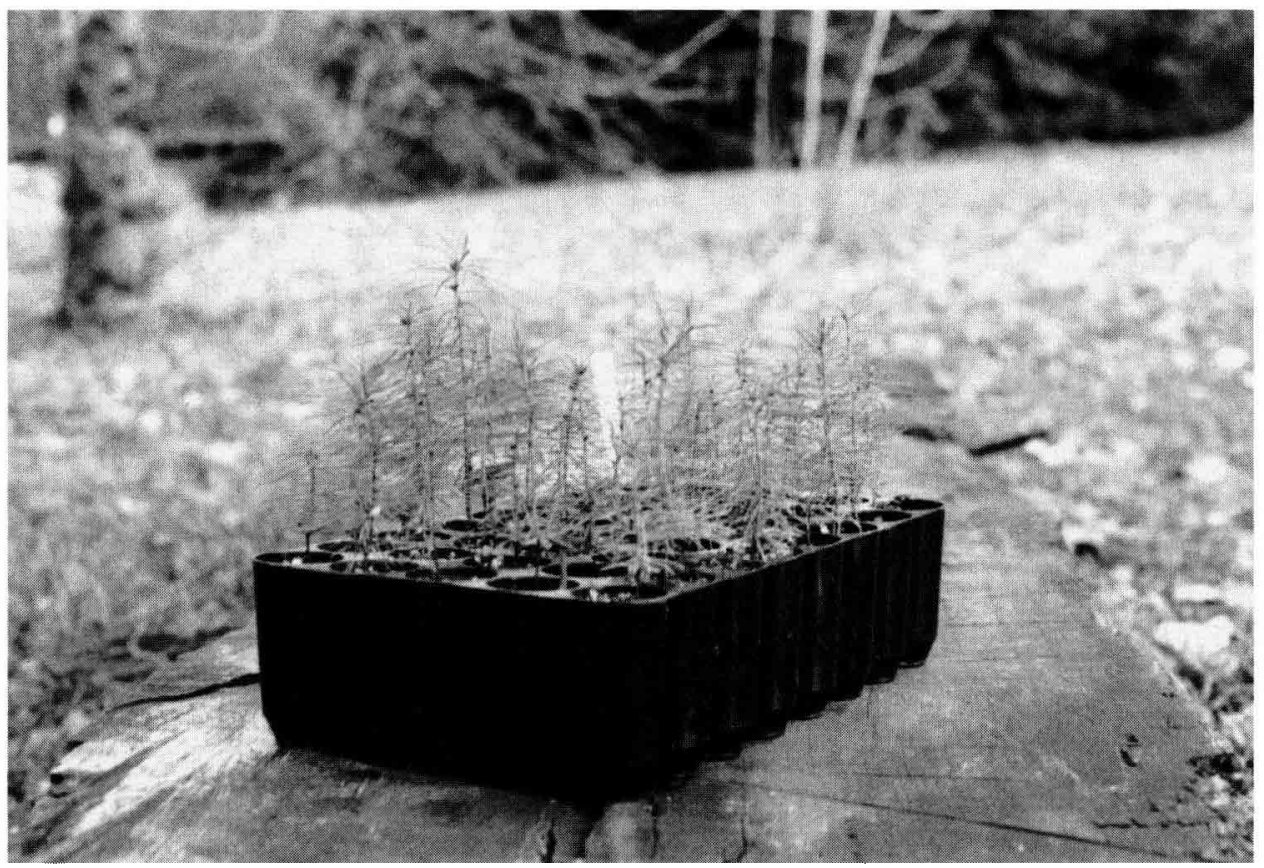

Fig 3. Six-month-old Douglas-fir seedlings in a set of Hiko containers ( 40 cells, $93 \mathrm{ml}$ each). 
$45^{\circ}$ in order to force root growth against the lower wall. Two or 3 seedlings are grown per box. This type of container presents the same advantages as the Petri dish system previously described for aseptic cultures: non-destructive observation of roots, sampling and various manipulations.

\section{Rootrainers (fig 5)}

These thermoformed PVC containers (Spencer-Lemaire Industries Ltd, Edmonton, Alberta, Canada) are like books forming cells when closed. The "books" are packed in trays. Different capacities are

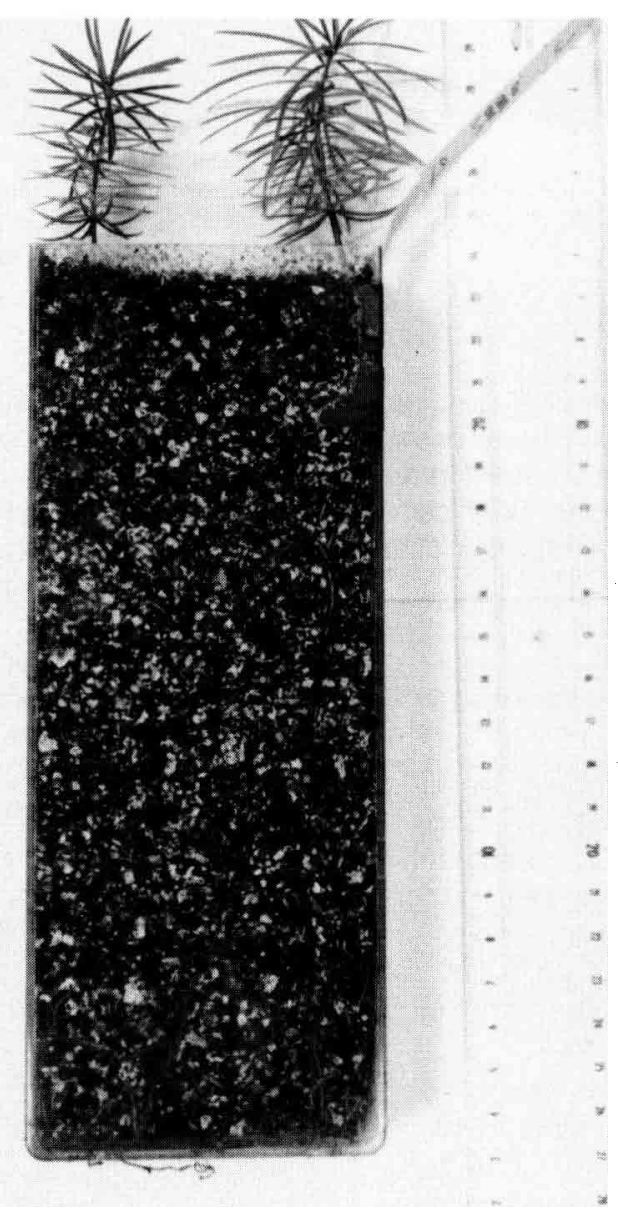

Fig 4. Six-month-old Douglas fir seedlings in a transparent box with vermiculite-peat substrate. 


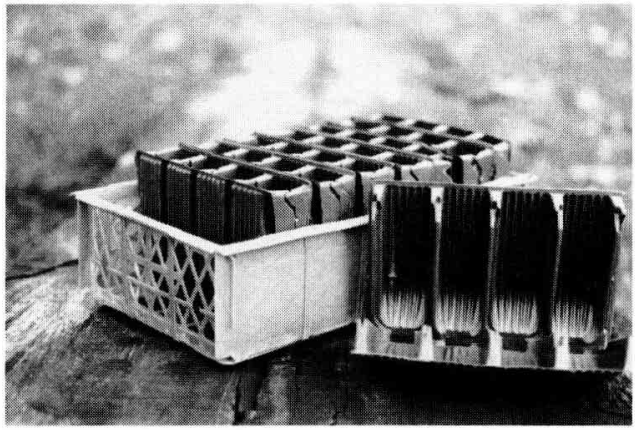

Flg 5. "Rootrainer" containers. The tray contains 32 cells, $115 \mathrm{ml}$ each. The "book" in the foreground is open.

available: $115,175,250$ and $1300 \mathrm{ml}$ per cell. Root and mycorrhiza development can be monitored any time by opening the "books". Rootrainers present the same drawback as Hiko containers when filled with flowing substrates.

\section{“M" containers (fig 6) (Riedacker, 1978)}

The " $M$ " containers (Thermoflan, MolièresCavaillac, Le Vigan, France) are made of 2 folded PVC parts, fitted into each other, which can be separated any time for nondestructive root observations. They are completely opened at the bottom and can only be filled with pure peat without plugging. Their capacity is $400 \mathrm{ml}$.

Whatever the container type, 2 or 3 seeds are sown per cell in order to ensure at least 1 germinating seed. When seedlings are 5 weeks old, they are thinned to 1 per individual container. When soil is used as a substrate, seedlings are watered daily with deionized water. When the

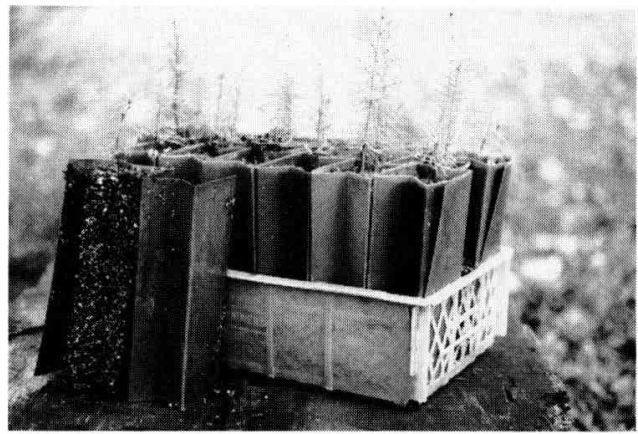

Fig 6. Six-month-old Douglas-fir seedlings in " $M$ " containers. The container in the foreground is open and shows the vermiculite-peat clump.

vermiculite-peat substrate is used, the following nutrient solution is applied in excess twice a week in addition to daily watering with deionized water: for 1 liter, $\mathrm{KNO}_{3}: 80 \mathrm{mg}$; $\mathrm{Ca}\left(\mathrm{NO}_{3}\right)_{2}, 4 \mathrm{H}_{2} \mathrm{O}: 19 \mathrm{mg}$; $\mathrm{NaH}_{2} \mathrm{PO}_{4}, \mathrm{H}_{2} \mathrm{O}: 9 \mathrm{mg} ; \mathrm{MgSO}_{4}, 7 \mathrm{H}_{2} \mathrm{O}: 74$ mg; Kanieltra: $10 \mu \mathrm{l}$. The composition of this solution has been experimentally determined in order to provide optimal mycorrhizal establishment. Concentrations of macroelements in $\mathrm{mg} \mathrm{H}^{-1}$ are: $\mathrm{P}: 1.8 ; \mathrm{N}$ : 33.5; $\mathrm{K}: 31.0 ; \mathrm{Ca}: 32.0 ; \mathrm{Mg}: 7.2$.

Fungal inoculation can be performed either by mixing vermiculite-peat or alginate inoculum throughout the substrate before filling the containers or by opening them when roots are well developed and spreading any of the 3 previously described inoculum types on the root system.

In all these glasshouse experiments, mycorrhizal infection begins 8 weeks after sowing. After one growing season (5-6 months), mycorrhizal rate can be close to $100 \%$ for seedlings $\approx 10-12 \mathrm{~cm}$ tall in the smallest containers. 


\section{LARGE SCALE SYNTHESIS IN BARE-ROOT NURSERY CONDITIONS}

The seeds are pretreated in moist sphagnum peat for 8 weeks at $4^{\circ} \mathrm{C}$ before sowing. The nursery soil, freshly tilled and at $10^{\circ} \mathrm{C}$ minimum, is fumigated in spring with cold methyl bromide ( $75 \mathrm{~g}$ per $\mathrm{m}^{2}$, soil covered with clear polythene film for 4 days). The film is removed 3 weeks before inoculating and sowing. Toxicity is eliminated during this time. This fumigation destroys all the microorganisms which can compete with the inoculated fungus (Le Tacon et al, 1983).

The nursery beds are divided into 0.5$\mathrm{m}^{2}$ plots separated from each other by 50 $\mathrm{cm}$ uninoculated and unsown zones. The fungal inoculum is broadcast and incorporated into the $10 \mathrm{~cm}$ topsoil at the dose of 2 I per $\mathrm{m}^{2}$ for peat-vermiculite inoculum (in this case, it it impossible to determine the quantity of mycelium) or 1 liter per $\mathrm{m}^{2}$ for alginate beads ( $2 \mathrm{~g}$ mycelium (dry weight) per $\mathrm{m}^{2}$ ).

The culture is managed using routine nursery practices except that fertilization is suppressed or considerably reduced, and that systemic fungicides are banned.

Under these conditions, mycorrhizal rate with Laccaria laccata ranges from 60 $80 \%$ at the end of summer, with seedlings $5-20 \mathrm{~cm}$ in height depending on the nursery. Under these nursery conditions, the effect of Laccaria laccata inoculation is dramatic: the seedling height is doubled if compared with an uninoculated control (Le Tacon et al, 1988).

In this case of all non-aseptic synthesis (glasshouse or nursery), seedlings uninoculated with $L$ laccata are mycorrhizal with Thelephora terrestris, a contaminant ectomycorrhizal basidiomycete which is very common as airborne spores in all temperate regions and adapted to these culture conditions. Therefore, it is generally impossible to produce non-mycorrhizal control seedlings.

Experiments using the techniques presented here can be found in Le Tacon et al (1983, 1985, 1987, 1988), Le Tacon and Bouchard (1986), Mortier et al (1988), Garbaye et al (1990) and Duponnois and Garbaye (1991).

\section{REFERENCES}

Dommergues R, Diem HG, Divies C (1979) Microbiological process for controlling the productivity of cultivated plants. US Pat No 4.155.737, May 22, 1979

Duponnois R, Garbaye J (1991) Mycorrhization helper bacteria associated with the Douglas fir-Laccaria laccata symbiosis: effects in vitro and in glasshouse conditions. Ann Sci For $48,239-251$

Garbaye J, Duponnois R, Wahl JL (1990) The bacteria associated with Laccaria laccata ectomycorrhizas or sporocarps: effect on symbiosis establishment on Douglas fir. Symbiosis 9, 267-273

Hacskaylo E (1973) Carbohydrate physiology of ectomycorrhizae. In: Ectomycorrhizae: Their Ecology and Physiology (Marks GC, Kozlowski TT, eds) Academic Press, NY, 207-230

Harley JL, Smith SE (1983) Mycorrhizal Symbiosis. Academic Press, NY

Le Tacon F, Jung G, Michelot P, Mugnier $J$ (1983) Efficacité en pépinière forestière d'un inoculum de champignon ectomycorhizien produit en fermenteur et inclus dans une matrice de polymères. Ann Sci For 40, 165-176

Le Tacon $F$, Jung $G$, Mugnier $J$, Michelot $P$, Mauperin $C$ (1985) Efficiency in a forest nursery of an ectomycorhizal fungus inoculum produced in a fermentor and entrapped in polymeric gels. Can J Bot 63, 1664-1668

Le Tacon F, Bouchard D (1986) Effects of different ectomycorrhizal fungi on growth of Larch, Douglas-fir, Scots pine and Norway spruce seedlings in fumigated nursery soil. Oecol App/ 74, 389-402 
Le Tacon F, Garbaye J, Carr G (1987) The use of mycorrhizas in temperate and tropical forests. Symbiosis 3, 179-206

Le Tacon F, Garbaye J, Bouchard D, Chevalier G, Olivier JM, Guimberteau J, Poitou N, Frochot $H(1988)$ Field results from ectomycorrhizal inoculation in France. In: Proceedings of the Canadian Workshop on Mycorrhizae in Forestry (Lalonde $\mathrm{M}$, Piché $\mathrm{Y}$, eds) Université Laval, Quebec, Canada, 51-74

Martin F, Delaruelle C, Hilbert JL (1990) An improved ergosterol assay to estimate the fungal biomass in ectomycorrhizas. Mycol Res 94, 1069-1074

Marx DH, Bryan WC (1975) Growth and ectomycorrhizal development of Loblolly pine seedlings in fumigated soil infested with the fungal symbiont Pisolithus tinctorius. For Sci21, 242-254

Mauperin C, Mortier F, Garbaye J, Le Tacon F, Carr G (1987) Viability of an ectomycorrhizal inoculum produced in a liquid medium and entrapped in a calcium alginate gel. Can $J$ Bot 65, 2326-2329

Melin E (1936) Methoden der experimentellen Untersuchung mykotropher Pflanzen. Handb Biol Arbeitsmethoden 2, 1015-1108
Molina R (1980) Ectomycorrhizal inoculation of containerized western conifer seedlings. USDA For Serv Res Note PNW-357

Mortier F, Le Tacon F, Garbaye J (1988) Effect of inoculum type and inoculation dose on ectomycorrhizal development, root necrosis and growth of Douglas fir seedlings inoculated with Laccaria laccata in a nursery. Ann Sci For 45, 301-310

Pachlewski R, Pachlewska J (1974) Studies on symbiotic properties of mycorrhizal fungi of pine (Pinus sylvestris) with the aid of the method of mycorrhizal synthesis in pure culture on agar. For Res Inst (Warsaw)

Riedacker A (1978) Étude de la déviation des racines horizontales ou obliques issues de boutures de peuplier qui recontrent un obstacle : applications pour la conception des conteneurs. Ann Sci For 35, 1-18

Shemakanova NM (1962) Mycotrophy of woody plants. In: Academy of Science of the USSR (Transl Israel Program for Scientific Transl, Jerusalem, 1967) Available from US Dept of Commerce, Springfield, IL

Vignon C, Plassard C, Moussain D, Salsac L (1986) Assay of fungal chitin and estimation of mycorrhizal infection. Physiol Vég 24, 201207 